\title{
ACTIVIDAD ECONÓMICA Y TRANSFORMACIÓN SOCIAL EN LA CIUDAD DE BARBASTRO DURANTE LA BAJA EDAD MEDIA
}

\author{
ECONOMIC ACTIVITY AND SOCIAL TRANSFORMATION IN THE CITY OF BARBASTRO \\ DURING THE LATE MIDDLE AGES
}

\section{María Teresa Sauco Álvarez*}

Resumen: El objeto de estudio del presente artículo es la ciudad de Barbastro en la Edad Media, desde sus orígenes como baluarte defensivo musulmán hasta su evolución como ciudad de significativa importancia a lo largo de la Baja Edad Media. Esta investigación presta especial atención al desarrollo de las estructuras de poder de la citada urbe durante el siglo $\mathrm{XV}$, en un momento en el que, gracias a la riqueza de las fuentes, se ha podido constatar con detalle el proceso madurativo del gobierno municipal y la imbricación del mismo con la irrupción en el panorama social del contingente converso.

Palabras clave: Barbastro, gobierno municipal, oligarquía local, conversos.

\begin{abstract}
The study object of this article is the city of Barbastro (Aragón, Spain) in the Middle Ages, from its origins as a defensive Muslim bulwark to its evolution as a city of significant importance throughout the Late Middle Ages. This research pays special attention to the development of the power structures of that city during the fifteenth century, at a time when thanks to the richness of documents, the maturation process of the municipal government and the interweaving of this development with the entry into the social landscape of the convert contingent have been noted in detail.
\end{abstract}

Key words: Barbastro, municipal government, local oligarchy, convert contingent.

* Tesis doctoral dirigida por el catedrático D. José Ángel Sesma Muñoz, enmarcada en el proyecto de investigación BHA2000-1342, Prosopografía de las sociedades urbanas en Aragón, siglos XIV-XV. Estrategias sociales y comportamientos individuales en los grupos dirigentes urbanos, del Ministerio de Educación y Ciencia, desarrollada gracias a las becas de investigación concedidas por la Institución Fernando el Católico y por el Gobierno de Aragón. 
El tema principal de la tesis doctoral Actividad económica y transformación social en la ciudad de Barbastro durante la Baja Edad Media fue seleccionado a partir de la relevancia de este enclave en época medieval dentro de la red urbana del reino de Aragón y de la riqueza de las fuentes documentales, a lo que se sumaba la carencia de un completo análisis sobre el citado objeto de estudio. Además es necesario incidir en que tal elección estaba integrada dentro de un proyecto de investigación de mayor envergadura, titulado Prosopografía de las sociedades urbanas en Aragón, siglos XIV-XV. Estrategias sociales y comportamientos individuales en los grupos dirigentes urbanos, subvencionado por el Ministerio de Educación y Ciencia y dirigido por el catedrático don José Ángel Sesma Muñoz. A partir de esta línea de investigación se llevaron a cabo varias tesis doctorales sobre destacados enclaves urbanos aragoneses que hasta ese momento apenas habían sido estudiados, con la finalidad de obtener mediante el conjunto de tales investigaciones un panorama global lo más detallado posible del entramado urbano aragonés y de sus estructuras sociales y económicas. ${ }^{1}$

Las fuentes documentales medievales que han perdurado sobre la ciudad de Barbastro son abundantes, de variada tipología y, sobre todo, complementarias. Gran parte de esta documentación se encuentra depositada en archivos de Barbastro, de Huesca y de otras pequeñas localidades de la zona que han conservado fondos medievales, principalmente pergaminos, como en Adahuesca, Alquézar y Salas Altas. En el caso del Archivo Municipal de Barbastro, los fondos custodiados son de una gran riqueza, ya que atesora la colección más completa de pergaminos, actas del concejo y protocolos notariales, además de numerosos legajos que aportan notable información sobre la época analizada. La citada colección de protocolos de este archivo queda complementada con la depositada en el Archivo Histórico Provincial de Huesca. El resto de archivos consultados, entre los que se encuentra el Archivo Histórico Provincial de Zaragoza, el Archivo Histórico de Protocolos de Zaragoza, el Archivo Histórico Nacional y el Archivo de la Corona de Aragón, han permitido ampliar los límites de la investigación al encontrar documentación de materias diversas,

1 Las tesis citadas son las de José Javier Medrano Adán, Iniciativas campesinas y sistema social en la montaña turolense: Puertomingalvo en el siglo XV, 2002; María Teresa Iranzo Muñío, El concejo de Huesca en la Edad Media. Estructura, funcionamiento y financiación de la organización municipal en la Baja Edad Media, 2004; Juan Abella Samitier, La villa aragonesa de Sos en la Baja Edad Media. Economía, sociedad y manifestaciones de poder, 2007; y Susana Lozano Gracia, Las elites en la ciudad de Zaragoza a mediados del siglo xv: La aplicación del método prosopográfico en el estudio de la sociedad, 2008. 
fundamentalmente relacionada con la gestión de la ciudad por parte del monarca, como localidad de realengo, y también sobre el patrimonio de las familias nobiliarias más importantes de este territorio, entre las que destacan los linajes Entenza y Castro.

Tras llevar a término la parte heurística de la investigación, fue necesario perfilar las líneas fundamentales de estudio. Esta reformulación del esquema de trabajo tras la labor de campo en los diferentes archivos consultados sirvió para ponderar la necesidad de detallar el proceso madurativo del gobierno municipal barbastrense durante el siglo xv, clave para comprender la evolución de la ciudad a finales del citado período. Este eje principal fue complementado con el análisis de las diferentes fuerzas de poder y su imbricación en la formación de una sólida estructura concejil, de creciente complejidad a lo largo de los siglos bajomedievales. De esta manera concejo, conversos y nobleza pasaron a conformar la estructura básica de la presente investigación, tres líneas de análisis totalmente interrelacionadas entre sí y fundamentales para comprender la sociedad barbastrense bajomedieval.

\section{La formación de las estructuras de poder de la ciudad}

El devenir de la ciudad de Barbastro en la Edad Media estuvo marcado por su estratégica ubicación como baluarte defensivo en una zona de transición entre las sierras pirenaicas y la depresión del valle del Ebro, aunando una orografía muy contrapuesta con un relieve escarpado al norte que se suaviza progresivamente conforme se desciende hacia el sur, favoreciendo el establecimiento de núcleos de población a medida que se amplían las posibilidades agrícolas y comerciales. La proximidad de los ríos Cinca y Ésera suponía una vía clara de acceso directo de norte a sur y las extensas llanuras de los somontanos permitían la comunicación de este a oeste, zona en la que destacan las depresiones de Huesca y Barbastro, conformando una vía de comunicación natural y un espacio de ocupación permanente.

Esta ubicación privilegiada explica tanto el origen del asentamiento a partir de un castillo defensivo musulmán, establecido con anterioridad al siglo IX, como su rápida conversión en madina poco tiempo después, así como la repercusión de su conquista por Pedro I en el año 1100, episodio significativo en el avance cristiano y hecho crucial para la ciudad. Barbastro estuvo totalmente influenciada por las características derivadas de este hecho, ya que en ese momento fue reconocida su titularidad como ciudad y como sede episcopal de 
manera estratégica, con la finalidad de reforzar su posición y alentar el avance cristiano frente a la presión musulmana. Por este motivo el monarca dotó a este enclave de una titularidad y unas franquicias que marcaron la personalidad jurídica de la ciudad durante los siglos subsiguientes (Laliena, 1996). El hecho de que algunas de las concesiones se hubieran extinguido con el tiempo o ciertos privilegios se hubieran diluido como consecuencia lógica de la evolución del contexto histórico, no mermó lo más mínimo la capacidad de reivindicación de Barbastro de los citados privilegios, al considerar que tales franquicias y libertades eran connaturales a su estatus de ciudad.

A partir de este momento la población cristiana se fue estableciendo en la ciudad y las estructuras institucionales fueron emergiendo progresivamente, incrementando su complejidad con el paso de los siglos. Las citadas concesiones dispensadas por el monarca mediante la carta de población del año $1099^{2}$ $\mathrm{y}$, muy especialmente, a través del fuero otorgado en el $1100,{ }^{3}$ fueron la base de la personalidad jurídica de la ciudad sobre la que se fue engarzando el organigrama concejil, en constante evolución durante los siglos ulteriores. Este fuero dotó a la población barbastrense de un estatus privilegiado mediante la concesión de la infanzonía a todos sus pobladores, considerándolos francos, libres e inmunes. Esta merced tan significativa, concedida con el propósito de premiar a los participantes en la conquista de la plaza y promover su poblamiento, influyó notablemente en la formación de los órganos de gobierno de la ciudad, propiciando la participación de los infanzones en el concejo municipal desde época temprana, hecho que llevaba implícita la contribución en determinadas cargas tributarias.

A pesar de que el privilegio conferido por Pedro I era extensivo a todos los pobladores de la ciudad, lo cierto es que en ningún caso supuso una homogeneización de los distintos grupos sociales, sino que en todo momento fueron patentes las diferencias entre los infanzones de natura y los de

2 El monarca se dirige "ad vos totos populatores quei venitis et veniretis populare ad illum meum kastellum de Barbastro et steteritis et popularetis ibi et in Barbastro quando Deus omnipotentis donavit no-

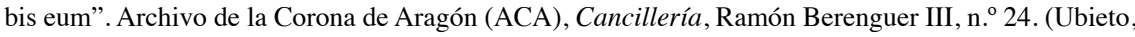
1951: 301).

3 El texto de este documento ha perdurado hasta la actualidad gracias a una confirmación de los fueros y privilegios dada por el rey Alfonso II en 1283, en la que fue copiado íntegro. Archivo Municipal de Barbastro (AMB), Pergaminos, 1/3. Durante los siglos XIX y XX se han realizado numerosas transcripciones de este fuero (Huesca, 1807: 459, apéndice 456-458; Quadrado, 1844: 160; Muñoz y Romero, 1847: 354-356; López Novoa, 1981 [1 $1^{\text {a }}$ ed. 1861]: 62-63; Lacarra, 1982: 31-33; Ubieto, 1951: 333-335; Angoy, 1984: 116-117; Ledesma, 1990: 45-46). 
población, ${ }^{4}$ dando lugar a frecuentes pugnas por el control del gobierno urbano. Estos enfrentamientos fueron habituales durante los siglos XIII y XIV, etapa en la que tanto infanzones como caballeros habían accedido a las magistraturas de justicia y jurados. El deseo, por parte de los ciudadanos, de restringir el acceso de la nobleza al gobierno urbano, en un intento por proteger su propia preeminencia dentro del organigrama concejil, dio lugar a la formación de bandos de gran significación que promovieron episodios de especial violencia, lo que implicó la intervención regia. El pacto entre infanzones y ciudadanos por el buen gobierno de la ciudad no se estableció hasta el siglo xv, a pesar de que con anterioridad ya se había llegado a acuerdos puntuales.

Nobles, infanzones y ciudadanos desequilibraron a menudo la frágil estabilidad existente entre estas fuerzas en su afán por controlar los principales resortes del poder municipal. Esta delicada situación también se vio afectada por las pretensiones sobre Barbastro de algunas familias nobles de renombre, como la casa de Castro y, especialmente, la casa de Entenza, que ejercieron en determinados momentos una presión excesiva sobre la ciudad en su empeño por imponer su primacía señorial. A ello debe sumarse que Barbastro era un feudo del rey, territorio de realengo, por lo que la ciudad no sólo debía fidelidad al monarca, sino que determinados bienes y rentas de la ciudad correspondían a la Corona. Aunque los beneficios obtenidos de las propiedades de realengo fueron del todo insuficientes para sustentar la administración regia, se trataba de unos ingresos atractivos que los diferentes monarcas del reino se aprestaron a preservar al máximo ante posibles alienaciones por parte de los nobles o ante injerencias del gobierno municipal. Por esta razón el infante Pedro, futuro Pedro IV, otorgó en 1329 unas ordenanzas a la ciudad de Barbastro con el fin de regular la protección de tales regalías, permitiendo que los jurados ciudadanos eligiesen a doce hombres buenos, escogidos asimismo entre los ciudadanos, para que tratasen con los jurados sobre los derechos y libertades concernientes a las regalías del rey, así como para defender las franquezas y privilegios de la ciudad, estableciendo que toda aquella persona que fuera en contra de tales premisas sería privada de participar en los oficios concejiles de manera vitalicia. ${ }^{5}$

El baile local de Barbastro, como agente de la administración real y guarda del patrimonio del monarca, era un cargo cuyo nombramiento fue realizado

4 Hay una clara diferencia entre los infanzones hermunios, herederos de este condición como descendientes de un linaje, frente a los infanzones de carta, que habían obtenido tal merced mediante un privilegio real, y sobre todo frente a los infanzones de población, los cuales habían adquirido la infanzonía a partir del citado fuero (Rogel, 2005: 27).

5 AMB, Pergaminos, 2/5. 
hasta el siglo Xv por el rey. Este oficial debía salvaguardar los bienes que el monarca tenía en la ciudad y estaba encargado de recaudar las rentas correspondientes a dichas regalías (Ladero, 1994: 31-93). El baile no tomaba parte en la elección de los cargos del concejo, pero como representante de rey debía velar por su correcto funcionamiento. Por esta razón los jurados entrantes debían jurar su cargo ante el justicia de la ciudad o, en su defecto, el lugarteniente de justicia, pero también debía estar presente el baile local. ${ }^{6} \mathrm{La}$ administración de justicia en la ciudad quedaba en manos del justicia, de manera que el baile no tenía capacidad de detener a ninguna persona si no era por mandamiento del justicia o su lugarteniente.

En el siglo XIII los caballeros e infanzones de Barbastro ya habían accedido a los oficios de justicia y jurados de la ciudad, hecho que dio lugar a multitud de controversias en el municipio. Los ciudadanos, en un intento por preservar su preeminencia en el concejo, obstaculizaron al máximo su acceso a los cargos municipales, derivando en una situación tan insostenible que el concejo hubo de solicitar ayuda al rey para conservar la paz en la ciudad. Tras la recepción de su súplica, Jaime II intentó pacificar dicha situación en 1295 mediante un escrito en el que instaba a la ciudad a restituir tanto a caballeros como a infanzones en los oficios de justicia y jurados, como se había venido realizando hasta ese momento de manera habitual. En cambio el consejo local, entendido como magistratura colegiada con funciones de asesoramiento al capítulo del concejo, continuó reservado a los ciudadanos hasta finales del siglo XIV. Por tanto se observa un acceso en época temprana de caballeros e infanzones a las magistraturas de justicia y jurados, pero el resto de cargos, incluido el de los consejeros, quedaron vetados a los nobles hasta fines del Trescientos.

El enfrentamiento entre los grupos nobiliarios y la clase dirigente de los ciudadanos por el poder se mantuvo durante los decenios siguientes, llegando a su punto culminante en 1387, momento en el que el gobierno de la ciudad solicitó de nuevo ayuda al monarca a causa de la situación insostenible que se estaba viviendo en la ciudad, lo que llevó al concejo a renunciar temporalmente a la facultad de elegir justicia. Este cargo era el de mayor relevancia dentro del organigrama concejil de la urbe, ya que tenía funciones gubernativas y judiciales, tanto en cuestiones civiles como criminales, y con jurisdicción tanto en la ciudad como en sus términos. 
El primer justicia de la ciudad fue Ato Galíndez, según consta en el fuero de Barbastro del año 1100, por designación real.7 Pero a partir de esta elección inicial, el rey confirió dicha libertad a la ciudad, aunque no se trató de una cesión plena, ya que el monarca debía confirmar a la persona elegida por el concejo. Ramos y Loscertales considera que esta licencia, también recogida en el fuero de Alquézar, no era propia del derecho aragonés, por lo que pudo estar influida por el derecho castellano o, más probablemente, proceder de la normativa sobrarbense, según la cual los infanzones de dicho territorio elegían a su justicia dentro de la curia regia (Ramos, 1981: 4).

A pesar de que dicha concesión aparecía claramente en el fuero de Barbastro y fue confirmada en numerosas ocasiones por diferentes monarcas, en muchos casos hubo reticencias por parte de la Corona para permitir que tal designación correspondiera a la ciudad, ya que la elección del cargo de justicia podía ser una interesante vía de injerencia real en el gobierno municipal. Pero tal merced fue fuertemente defendida desde el concejo, el cual no estaba dispuesto a renunciar a la gran autonomía que le confería el hecho de poder elegir justicia entre sus conciudadanos. ${ }^{8}$ Así lo corroboró a principios del siglo XIV Jaime II, después de haber expresado sus recelos sobre tal concesión, lo que le llevó a iniciar una investigación sobre dicho asunto mediante la revisión de todos los privilegios concedidos por sus antecesores a la ciudad. Finalmente concluyó que había de ratificar, de nuevo, la facultad de la ciudad para elegir anualmente en el mes de octubre tanto al justicia como a los jurados de Barbastro, subrayando que la confirmación del cargo de justicia debía ser realizada por el monarca o por el baile general en su defecto, mientras que la elección de los jurados no necesitaba ratificación alguna por parte del rey. ${ }^{9}$

En 1387 Barbastro estaba viviendo un momento de excepción en el que las luchas entre bandos se habían adueñado de la ciudad y desde el gobierno municipal se temía una «irreparable destruccion». ${ }^{10}$ Vista la imposibilidad de mediación, el concejo barbastrense solicitó ayuda a Juan I, dejando en sus manos la elección del justicia de la urbe durante dos años, pero siempre sin lesión de los fueros, privilegios, libertades y franquezas de la ciudad. Pasado ese plazo el monarca continuó designando al justicia de la ciudad durante un

7 AMB, Pergaminos, $1 / 3$.

8 ACA, Pergaminos de Juan I, Carpeta 308, Pergamino 93.

9 AMB, Pergaminos, 1/10. ACA, Cancillería, Registros, núm. 203, ff. 105-v.

10 ACA, Pergaminos de Juan I, Carpeta 308, Pergamino 93. 
tiempo bastante prolongado, lo que lleva a pensar que la situación de excepción generada por la lucha de bandos no mejoró inmediatamente tras la intervención regia. ${ }^{11}$

La ciudad de Barbastro tardó varios decenios en recuperar la facultad de elegir al justicia, ya que en torno a 1415 dicha designación todavía perduraba en manos del monarca. ${ }^{12}$ Se trataba de un momento especialmente cambiante para la ciudad, marcado por la conversión forzosa de los judíos barbastrenses en torno a 1414 y la incautación del patrimonio de la familia Entenza por parte de la monarquía en 1417, a causa de su parentesco con Jaime II, conde de Urgel, como represalia por su levantamiento contra el rey Fernando I (Sesma, 2011; Sesma, 2012; Rubio, 2012: 265-291; VV.AA., 2013). Estos dos acontecimientos afectarían al devenir de la ciudad en los decenios posteriores, así como al desarrollo del gobierno municipal, especialmente por la rápida integración de los judíos conversos en el organigrama municipal. Una vez que el concejo recuperó la potestad de nombrar justicia en el siglo Xv, se volvió a practicar un reparto en el ejercicio del cargo entre caballeros e infanzones y ciudadanos, como ya se había realizado durante el XIV.

Otra fecha significativa para la ciudad fue 1454 , año en el que tuvo lugar en Barbastro una reforma del proceso de elección de los oficiales del concejo, al igual que había acontecido en muchas otras ciudades de la Corona de Aragón, que supuso pasar de elegir a los miembros del concejo mediante cooptación a utilizar el procedimiento de la insaculación, uno de los sistemas electorales más difundidos durante el Antiguo Régimen (Torras, 1986: 341). En algunos casos se había pasado de la cooptación a un sistema que combinaba cooptación y azar, mediante el uso de sacos, como en las ciudades de Zaragoza y Valencia, pero en Barbastro no se observa esta fase intermedia (Batlle, 1988: 68; Falcón, 1978; Hinojosa, 1988: 42; Narbona, 2007: 113-150). Hasta esa fecha, los oficiales del concejo barbastrense habían sido elegidos mediante cooptación. En 1445, uno de los pocos años previos a la reforma insaculatoria del que han perdurado actas del concejo, los oficiales salientes prometían «bien et lealment haver et esleyr los officiales a utilidat de la cosa publica», ${ }^{13}$ habiendo de designar al justicia, seis jurados y al notario de la ciudad. De la misma forma que se había realizado un reparto del ejercicio del cargo de justicia entre ciudadanos e infanzones, también se estableció una cuota en el caso de los jurados, de

11 AMB, Pergaminos, 3/13. AMB, Pergaminos, 3/14.

12 ACA, Real Patrimonio, Receptores de las Rentas del Rey, sign. 2659, ff. 106-107.

13 AMB, Actas del Concejo, 1445-1446, ff. 104v-105. 
manera que cuatro de ellos habían de ser ciudadanos y otros dos hidalgos, pacto posteriormente plasmado en las ordenanzas insaculatorias de 1454. El hecho de que los oficiales salientes fueran los encargados de nominar a los entrantes generó abundantes discordias. En 1453 el número de habitantes y ciudadanos de Barbastro que habían iniciado firmas de derecho u otras provisiones contra el concejo por no haber entrado a formar parte del gobierno municipal fueron tan elevados, que el concejo tuvo que amenazar con emprender acciones legales contra ellos, según la normativa fijada en los estatutos de la ciudad. ${ }^{14}$

La primera ciudad del reino de Aragón que asumió el sistema insaculatorio fue Zaragoza, entre 1442 y 1443. Pocos años después, en 1445, la reina María, como lugarteniente del rey Alfonso V, estipuló que este sistema debía ser establecido en determinadas ciudades, villas y lugares del reino, ${ }^{15}$ entre las que se encontraba Barbastro. El ritmo de implantación fue muy diverso, como puede deducirse de que en la localidad barbastrense no se introdujera la citada reforma hasta nueve años después, mientras que en otros núcleos de población se impuso el nuevo sistema de forma casi instantánea. En general se observa una introducción paulatina del sistema insaculatorio en el reino durante el reinado de Alfonso V, produciéndose su verdadera difusión durante el reinado de Fernando II.

La implantación del sistema insaculatorio en 1454 en Barbastro como medio para elegir a los cargos concejiles validó el reparto de oficios entre los grupos urbanos, ratificando de esta manera el pacto existente desde hacía décadas entre ciudadanos e infanzones para el gobierno de la ciudad, aunque quedó patente el claro predominio de los ciudadanos. Pero el equilibrio de poder fijado mediante tales ordenanzas tuvo una vigencia relativa, ya que durante la segunda mitad del siglo xv las reformas del sistema fueron constantes, con la consiguiente elaboración de nuevas bolsas, momento determinante en el reparto de poder.

La clave de la cristalización de este sistema, impulsado por el monarca y alentado por los grupos urbanos, fue la legitimación en el poder. Se trataba de un sistema que, aunque permitía la injerencia real, dotaba a los grupos dirigentes de cierta autonomía (Falcón, 1978: 87). Según Torras i Ribé, este sistema

14 Archivo Histórico Provincial de Huesca (AHPH), Actas del Concejo, 1452-53, ff. 62-63.

15 Las localidades citadas son Huesca, Sariñena, Alquézar, Aínsa, Barbastro, Ejea de los Caballeros, Jaca, Tauste, Sos, Uncastillo, Sádaba y Murillo de Gállego. ACA, Cancillería, Registros, núm. 3139, ff. 20v$21 \mathrm{v}$. 
fue positivo para la regulación de la vida social y política de las ciudades, ya que sirvió para plasmar de manera fehaciente el reparto de poder entre los distintos grupos sociales que formaban parte del gobierno urbano, estipulándose una formulación estamental. Por tanto, se introduce un concepto de representación ciudadana proporcional a la «calidad, riqueza e influencia intrínseca de cada estamento en el seno de la sociedad» (Torras, 1986: 343) y no al número de habitantes, por lo que el ciudadano deja de ser miembro de la colectividad y pasa a ser el individuo de una clase.

En las ordenanzas de Barbastro otorgadas en 1454 (Arco, 1946: 455-468; Angoy, 1984: 147-159), promulgadas por Juan de Navarra, gobernador de Aragón y futuro rey, se subraya la necesidad de corregir la corrupción y nepotismo surgidos de la cooptación mediante la introducción del sistema insaculatorio, con la finalidad de lograr el «dreçamiento e reparacion del regimiento de la ciudat, de modo que se evitaran discordias e debates que se parellavan suscitar sobre el dito regimiento e se perpetuara paz e concordia entre los ciudadanos e fidalgos». ${ }^{16}$ En dicho documento se estipula el número de cargos que debían conformar el concejo, así como si debían ser ocupados por ciudadanos o por infanzones, y el cursus honorum que debían realizar los oficiales. El concejo quedaba integrado por 28 personas, repartidas entre los cargos de justicia (1), jurados (6), almutazafes (2), bolsero (1) y consejeros (18), ${ }^{17}$ elegidos mediante doce bolsas. ${ }^{18}$

En el caso del oficio de justicia fueron creadas dos bolsas, la de «justicia de ciudadanos» y la de «justicia de fidalgos», ya que este cargo debía elegirse de forma alterna entre ambos grupos, aunque con preeminencia del contingente ciudadano, ya que el redolino se extraía durante dos años de la bolsa de los ciudadanos y, al tercer año, se alternaba la bolsa y se utilizaba la de los infanzones. Para la elección de los jurados se crearon inicialmente cinco bolsas, tres de ciudadanos y dos de infanzones. Las bolsas de los ciudadanos eran las de prior de los jurados, jurado segundo y juez de misa matinal y la de jurados tercero y cuarto. Mientras que en el caso de los infanzones se formó la bolsa

16 AMB, Pergaminos, 8/a y 8/b [1454/VI/14].

17 «Statuymos e ordenamos que por al regimiento de la dita ciudat sian puestos en aquella los officiales siguientes, es a saber, un justicia, el qual sia dos anyos arreu saccado de ciudadanos e el tercero de [hidalgos, se]ys jurados, de los quales sian los quatro ciudadanos e los dos fidalgos, dos almudacaffes, un bolsero de ciudat e dizeocho conselleros, los dotze ciudadanos e los seys fidalgos». Ibídem.

18 Este número de bolsas contrasta con otros casos mucho más sencillos, como acontece en Alicante, donde únicamente se crean dos bolsas, una mayor, para la elección del justicia y jurados, y otra menor, para seleccionar al resto de oficiales (Hinojosa, 1988: 54). 
de jurado primero y juez de misa matinal de los infanzones y la de jurado segundo. Los consejeros debían ser dieciocho, doce ciudadanos y seis infanzones, pero su elección se realizaba en grupos de seis, ya que los consejeros ciudadanos debían ser extraídos de dos bolsas distintas, la de los consejeros ciudadanos más honorables y la de los consejeros de menor dignidad. En cambio los infanzones únicamente contaban con una bolsa de consejeros.

Otros cargos que debían ser electos mediante redolinos y que, por tanto, se necesitaba crear las bolsas, eran el de bolsero y almutazafes, ambas integradas únicamente por ciudadanos. Además también se creó desde un primer momento la bolsa para elegir a los procuradores para Cortes generales, integrada por ciudadanos, y la bolsa de mensajeros para otras cuestiones, formada por ciudadanos e infanzones. La extracción de redolinos en estos dos últimos casos se llevaba a cabo únicamente cuando la ocasión lo requería, por lo que dicha elección no se realizaba el mismo día que el resto de los cargos ni existía un número determinado de personas que debiesen ejercer tales oficios.

A lo largo de la segunda mitad del siglo Xv se fueron creando nuevas bolsas o se modificaron algunas de las descritas en las ordenanzas de 1454 . Este documento sirvió para ratificar el pacto existente desde hacía décadas entre ciudadanos e infanzones para el gobierno de la ciudad, aunque quedó patente el claro predominio de los ciudadanos en el caso de los cargos relevantes del concejo, ya que controlaban de forma mayoritaria los cargos de justicia, jurados y consejeros y dominaban totalmente los cargos de bolsero y almutazaf, lo que suponía supervisar los aspectos económicos del municipio, así como la contabilidad del concejo. En el caso de los cargos de justicia, jurados y consejeros, los porcentajes de participación eran idénticos, ya que tanto en el caso de los jurados como en el de los consejeros, el 67\% eran ciudadanos. En el caso del justicia, teniendo en cuenta el ciclo temporal de tres años, durante los cuales el cargo era ejercido dos veces por ciudadanos y una por infanzones, se constata la misma cifra de participación del 67\%. A pesar de que este acuerdo mostrase una clara predominancia del grupo ciudadano, era bastante favorable para los infanzones si se compara con otras ciudades que habían llegado a realizar pactos similares, como en el caso de Huesca (Iranzo, 2005).

Las Ordinaciones reales de la ciudad de Barbastro de 1657 dejan constancia de la larga perduración del pacto forjado entre los ciudadanos e infanzones de la ciudad, existente todavía en el siglo XVII: 


\begin{abstract}
Por quanto la experiencia ha mostrado ser conveniente al buen gobierno de la ciudad de Barbastro la union que en tienpos se hizo en los oficios de ella de infançones y ciudadanos y como tal los comissarios reales, nuestros predecessores, la han siempre prorrogado, por tanto, confirmando, prorrogando y aprobando la dicha union, estatuymos y ordenamos que aquella se continue, prorrogue, observe y guarde de la forma que hasta aqui se ha observado y guardado, la qual Nos continuamos y prorrogamos por tiempo de treinta años (Ordinaciones reales de la ciudad de Barbastro, 1657: 1-2).
\end{abstract}

Mediante la regulación del ritmo de crecimiento o cambio de las bolsas, con el fin de evitar desequilibrios o desórdenes, se establecieron las pautas del cursus honorum que podían realizar los oficiales hasta acceder al justiciado. Aquellas personas que desearan ser jurados debían solicitar su admisión para la bolsa de jurados tercero y cuarto, si eran ciudadanos, o de jurado segundo de hidalgos, en el caso de que fueran infanzones. A partir de aquí podían ir ascendiendo por las bolsas de jurados de forma progresiva, respetando los lapsos de tiempo estipulados y la cantidad límite de personas que podían cambiar de bolsa. Tanto los jurados segundo, tercero y cuarto de ciudadanos como el segundo de hidalgos debían permanecer como mínimo dos años en las citadas bolsas, siempre a partir de la fecha de su ingreso. Una vez que hubieran accedido a las bolsas de prior de los jurados o de jurado primero de hidalgos, respectivamente, debían permanecer en ellas un mínimo de un año. Tras todos esos pasos, ya se encontraban en disposición de optar al justiciado de la ciudad. En este sentido el cursus honorum de los infanzones era más corto, ya que únicamente tenían que pasar por dos cargos antes de optar al de justicia, pero debe tenerse en cuenta que los infanzones únicamente accedían a ese puesto clave una vez cada tres años, ya que los otros dos años el oficio era ejercido por ciudadanos.

Para controlar el acceso a los cargos de mayor relevancia, tanto al de justicia como a los de prior de los jurados, jurado segundo de ciudadanos, jurado primero de hidalgos, así como el de bolsero, únicamente se aceptaba la inclusión de una persona en cada una de dichas bolsas durante la ceremonia de promoción, que tenía lugar cada dos años. Este número se incrementaba a dos en el caso del resto de las bolsas de jurados, de almutazafes y de consejeros de hidalgos, y a tres en las dos bolsas restantes de consejeros, es decir, las correspondientes a los ciudadanos de mayor y menor dignidad. Solamente se contemplaba como excepción que en el caso de que las bolsas de justicia y jurado primero de hidalgos se hallaran casi vacías a causa del fallecimiento de sus miembros, entonces se pudieran añadir más redolinos de una sola vez hasta 
llegar a seis en total junto con los que ya formasen parte de dichas bolsas. Conforme avanza la segunda mitad del siglo Xv se observa una dificultad creciente a la hora de elegir a nuevos oficiales, ya que en algunos casos el número de personas hábiles era totalmente insuficiente debido a que parte de los miembros de cada bolsa ya habían sido designados oficiales, por lo que debían respetar el plazo de tiempo estipulado para volver a ejercer el cargo, y otro porcentaje había fallecido, lo que mermaba considerablemente las opciones.

Esta detallada reglamentación del cursus honorum permitía una rotación de las elites dentro de las magistraturas, pero también suponía una perpetuación en el poder, ya que los jurados salientes podían ser incluidos en la bolsa de consejeros al año siguiente de salir del cargo y ejercer este nuevo oficio pasado un año de haber sido jurados. Esta permanencia en el poder se hizo más patente todavía al incluir la figura de los «consellyeros de piet» dentro de la nómina del concejo a partir de los años 60 del siglo xv, los cuales eran los jurados salientes del año anterior. Por tanto, cuando un individuo entraba a formar parte de una bolsa, no sólo tenía la posibilidad de ejercer un oficio, sino que iniciaba toda una carrera dentro del gobierno municipal. Además de ello, el hecho de ser seleccionado y aceptado como miembro hábil para ser insaculado suponía todo un reconocimiento de su condición estamental (Santamaría, 1988: 25).

El acceso o promoción entre bolsas no era un proceso sencillo, ya que los candidatos no sólo debían esperar dos años a que se convocase el acto, cumplir los requisitos, acatar los plazos de promoción y esperar que fuera favorable la votación mediante la fabeación, sino que además su solicitud debía ser admitida, circunstancia que no acontecía en todos los casos. La elección de personas que no hubieran probado su hidalguía para ejercer cargos correspondientes a los infanzones o que se consideraran dudosas generó numerosos conflictos, lo que llevó al concejo a acordar que toda aquella persona que se declarase infanzón, pero no lo hubiera probado, sería considerado inhábil para ejercer los correspondientes oficios.

En 1457 se realizaron las primeras modificaciones de las ordenanzas de 1454, a pesar de que habían sido otorgadas con una validez de 10 años, mediante una comisión de la reina María otorgada el 15 de marzo de ese mismo año (Arco, 1946; Angoy, 1988). Como indica Iranzo, era frecuente la realización de este tipo de reformas en diferentes fases, ya que en un primer momento se establecían las bases generales del sistema y, posteriormente, se pergeñaban los detalles en función de las necesidades concretas de cada lugar (Iranzo, 
2005). La realidad es que, además de las correcciones llevadas a cabo en 1457, durante toda la segunda mitad del siglo xv la estructura concejil barbastrense se fue haciendo más compleja, incrementando progresivamente tanto el número de cargos como el de personas que formaban parte del concejo. El 30 de junio de 1466 fueron otorgadas nuevas ordenanzas por el gobernador del reino, ${ }^{19}$ a causa de la pérdida de vigencia de las disposiciones anteriores, de 1454. Y lo mismo aconteció en 1475, año en el que se requirió de nuevo al monarca la renovación del privilegio de la insaculación durante diez o quince años más. ${ }^{20}$

En 1486, tras once años de la última reforma del proceso insaculatorio, la elección de los oficiales sufrió graves irregularidades, ya que dejó de utilizarse la extracción de los cargos mediante ceruelos ${ }^{21}$ y los oficiales pasaron a ser elegidos de nuevo mediante cooptación ejercida por los jurados de los tres años precedentes, correspondientes a 1483, 1484 y 1485. Los cargos designados fueron los mismos que en años anteriores, excepto en el caso del capdeguayta ${ }^{22}$ cargo que desapareció definitivamente del organigrama concejil barbastrense. En el caso de la elección de los consejeros no fue posible lograr la unanimidad entre todos los miembros electores, lo que llevó a plantear otras opciones de selección. Finalmente tales discrepancias se solventaron al acordar que los consejeros de 1486 fueran los oficiales del trienio anterior, a los que se añadieron seis personas más para llegar al número de veintiuno, elección irregular que se produjo de nuevo en $1487 .{ }^{23}$

A partir de 1489 se reestableció la elección de los cargos municipales mediante el sistema de la insaculación, según las ordenanzas nuevas dadas por Alonso de Aragón, lugarteniente general del reino y arzobispo de Zaragoza, hijo natural de Fernando el Católico, por las que le abonaron 3000 sueldos al monarca en $1490 .{ }^{24}$ Esta nueva regulación, si bien retomó parte de las directrices de estatutos precedentes y reimplantaron la insaculación en la ciudad, no sirvieron para recuperar totalmente el orden quebrantado en la organización concejil barbastrense durante los últimos años, hecho que aprovechó el monarca para intervenir en el gobierno de la ciudad (Aranda y Sanz, 2003: 55). Esta

19 AMB, Actas del Concejo, 1468-69, ff. 2-v.

20 AMB, Actas del Concejo, 1475, ff. 14-15.

21 Bolas de cera del mismo peso y tamaño, también denominadas redolinos, que guardaban en su interior un pequeño pergamino con el nombre de las personas que optaban a ser elegidos para el cargo.

22 Jefe de guardas locales. (López Susín, J. I., 2008-2009: 92).

23 AMB, Actas del Concejo, 1486-87, ff. 3-v, 5-v; 1487-88, ff. 1-v.

24 AMB, Actas del Concejo, 1489-90, ff. 2-v, 25. 
injerencia real se materializó en 1492 al ordenar a la ciudad que se sobreseyera la extracción de los oficios. Posteriormente el monarca encargó al jurista Luis de Castillón, ciudadano de Zaragoza, como asesor del gobernador del reino, la reparación de las capitulaciones de selección de cargos de la ciudad, «atendido los grandes desordenes que en cada extraccion se fazian $» .{ }^{25}$ Cinco meses después, el 8 de agosto de 1493, el rey Fernando confirmó en Barcelona las ordenanzas elaboradas por Luis de Castillón, con una validez de diez años, por lo que el concejo tuvo que abonar 3000 sueldos en Zaragoza como pago por tal reparación. ${ }^{26}$

Durante la Baja Edad Media, el concejo barbastrense tuvo un relevante papel de gestión sobre la producción y el comercio de productos básicos, por lo que aplicó férreas medidas de control con el fin de promover la autosuficiencia de la ciudad y garantizar la subsistencia de la población, además de fomentar la protección del consumidor local (Mateos, 2005-2006: 105-132). Para lograr estos objetivos se impusieron desde el concejo políticas intervencionistas en momentos críticos, con el fin de evitar conflictos y asegurar los productos básicos para la población, y medidas proteccionistas en etapas con un rendimiento agrícola más pujante. El arrendamiento de bienes raíces y monopolios era una vía significativa de ingresos para el concejo barbastrense, el cual los transfería mediante subasta pública al mejor postor, que solía pertenecer a los grupos más pudientes de la ciudad, habitualmente conversos. Entre los monopolios cedidos por el gobierno municipal para su gestión destaca principalmente el comercio de aceite, las taulas de las carnicerías y el puesto del pescado (Falcón, 1997: 239-274; Falcón, 1999: 191-218; Mateos, 2003: 51-77; Sánchez, 2010: 45-66).

La zona correspondiente al actual Somontano de Barbastro se caracterizaba por la producción de trigo, vino y aceite en la Baja Edad Media (Navarro, 2006: 87-100). El paisaje agrícola barbastrense estaba dominado por viñedos y olivares, además de grandes zonas de pasto que fueron creciendo a lo largo del siglo Xv, debido a la necesidad de alimentar a las cabañas ganaderas y así disponer de carne y otros productos para la subsistencia de la ciudad y zonas limítrofes. Los cultivos de cereal también estuvieron presentes en este territorio, donde se cultivó primordialmente trigo y cebada, pero también centeno, ordio, segal y mijo. Pero a pesar de este panorama, el cultivo del cereal no fue lo su- 
ficientemente productivo como para garantizar el correcto abastecimiento de Barbastro en época bajomedieval. Por este motivo el concejo, como supervisor del abastecimiento de alimentos de la ciudad, tuvo un interés constante por conseguir una correcta provisión de grano, especialmente de trigo, patente desde el siglo XIv. En las ordenanzas dadas por la ciudad en 1396 (Vázquez, 2011), ya se refleja esta preocupación por paliar los problemas de desabastecimiento de la ciudad, ya fuera por escasez de la materia prima como por falta de personal que pudiera desempeñar las labores necesarias para que tanto los cereales como el pan cocido pudieran llegar hasta el consumidor. Por este motivo correspondía a los oficiales del concejo «cura carnis, panis et aliorum ad habundantium vittualium in dicta civitate». ${ }^{27}$ Los almutazafes debían controlar que hubiese «bastamento de pan cozido e de carne, por manera que toda persona por su dinero en de pueda comprar» (Vázquez, 2011: 39). Además el gobierno municipal también debía encargarse de nombrar a los paniceros, así como establecer los precios de venta. Se trataba de un ámbito muy controlado desde el gobierno municipal, por ese motivo no se dudó en actuar contra todo aquel que hiciese «pan franco» en la ciudad.

La necesidad de abastecimiento de cereal, en concreto de trigo, llevó al concejo a tener que ir al encuentro de proveedores en otras zonas. La búsqueda de este producto se realizó inicialmente en localidades circundantes, como Binaced, a 25 kilómetros de distancia. Pero la imposibilidad de hallar las cantidades de grano necesarias en momentos de escasez supuso que los mercaderes tuvieran que viajar a zonas algo más alejadas, como Sariñena y Ontiñena, a 45 y 60 kilómetros de Barbastro, respectivamente, e incluso recurrir a transacciones de mayor distancia y llegar a importar trigo desde Cataluña. Así aconteció a mediados de siglo, momento en el que la escasez de este cereal en la ciudad dio lugar no sólo a importaciones puntuales de larga distancia, sino incluso a pactos que asegurasen una provisión regular semanal de trigo para comercializarla cada martes, día de mercado en Barbastro (García Marsilla, 1993: 95-144; Narbona, Cruselles, 1995: 305-332; Orti, 1999: 423-445; Cateura, 2006; Guinot, Mira, 2008: 137-161; De la Torre, 2016: 185-210).

El aceite también era uno de los productos regulados desde el concejo a finales de la Edad Media. Las medidas que se hubieron de tomar desde el gobierno municipal con respecto a este producto variaron considerablemente en función de las características de la producción. El concejo implantó desde po- 
líticas intervencionistas en la venta al por menor en momentos de carestía, con la finalidad de controlar los precios y evitar la inflación, hasta medidas proteccionistas en momentos de mayor bonanza, centradas en frenar totalmente la importación de este producto, aunque fuera desde lugares tan cercanos como Alquézar, Colungo o Adahuesca, apenas a 25 kilómetros de la ciudad.

La comercialización de otros productos tan relevantes como la carne y el pescado también estuvo marcada por las directrices municipales. En el caso de la carne, había tres puntos de venta, aunque únicamente dos eran controlados desde el concejo, que arrendaba su uso. Estos puestos estaban situados en el Mercado y Riancho ${ }^{28}$ y eran gestionados por población cristiana. El tercer lugar de abastecimiento era la carnicería de los moros, situada en La Fustería. Este último establecimiento, perteneciente a la familia Entenza desde su concesión a Pedro II de Urgel por parte de Pedro IV en el siglo XIV, se convirtió en una fuente constante de conflicto entre los Entenza y el concejo. La concesión original especificaba que se trataba de una carnicería para los moros, pero en fecha temprana ya se vendía carne a los cristianos. Esta irregularidad, considerada muy grave, dio lugar a que el concejo prohibiese totalmente a la población cristiana que comprase en dicho establecimiento, amparándose en que el privilegio del siglo XIV únicamente hacía referencia al comercio con sarracenos y, en cambio, se estaban vendiendo «carnes, assi de carnero como de otros animales, a saber es, de bueyes, crabones, corderos y terneros, y por aquel precio que cada qual de los dichos animales en la dicha carneceria se havian acostumbrado vender no solamente a los dichos moros, mas ahun a los cristianos de la dicha ciudat e otros qualesquiere que a la dicha ciudat viniessen y de aquellas quisiesen comprar». ${ }^{29}$ Las disputas con el concejo sobre este tema fueron aparentemente zanjadas por el rey Alfonso V el 18 de noviembre de 1453 mediante un privilegio en el que el monarca rubricaba el derecho a «vender en la dicha carneceria carnes, no solamente a los moros, mas ahun a los cristianos», ${ }^{30}$ pero a pesar de esta intervención, el conflicto perduró hasta bien entrado el siglo XVI.

En cambio las tablas del Mercado y de Riancho estaban bajo control directo del concejo, que procedía a arrendarlas periódicamente. Únicamente debía tenerse en cuenta que el arrendatario de uno de los puestos no podía tomar parte en el otro, ya fuera de manera directa o indirecta, con el fin de evitar un

28 AMB, Actas del Concejo, 1469-70, f. 32v.

29 AMB, Pergaminos, 12/10. AMB, Legajos, D13-15.

30 Ibídem. 
excesivo monopolio de la comercialización de carne por parte de la misma persona. El puesto de Riancho tenía más beneficios que el del Mercado, por lo que normalmente se arrendaba por un precio superior. Era frecuente sacarlo a subasta antes que la taula del Mercado, para intentar conseguir un buen negocio también en el segundo caso. ${ }^{31}$

En Barbastro también se consumía pescado fresco, seco y salado, marítimo y fluvial. Se trataba de productos muy delicados, de rápida putrefacción, por lo que una correcta manipulación y transporte eran básicos para asegurar su calidad (Rodrigo, 2009: 547-577). Hasta mediados del siglo xv los «mercaderos, revendedores e revendederas» de Barbastro eran convocados el miércoles de ceniza en la iglesia de San Bartolomé para que explicitasen la provisión de pescado y de otros productos básicos que tenían para comercializar, tanto en Cuaresma como durante el resto del año, de manera que el concejo pudiese calcular las necesidades de la población, tanto de la ciudad como de los núcleos limítrofes. Pero, a partir de 1450, el concejo decidió modificar este sistema, ya que el año anterior los comerciantes y vendedores apenas se habían abastecido correctamente, lo que «redundava en deservicio de Dios y en mala provision de los vezinos et habitadores de la ciudat et los venientes ad aquellya». El concejo, en un intento por asegurar el abastecimiento, optó por arrendar cada diciembre «a personas poderosas et sufficientes» el monopolio de la pesca y otros productos, porque «no seria cosa condescent una tal ciudat como aquesta e los venientes en aquellya no fuessen bien proveydas». ${ }^{32}$ Ese mismo año, el ciudadano Luis de Pueyo se hizo con el citado monopolio durante tres años, a partir del primer día de Cuaresma, por la nada desdeñable cantidad de 850 sueldos anuales, la mejor oferta que los corredores pudieron encontrar. Inicialmente se estableció que el pago de la arrendación se abonase en dos plazos, el primero seis meses después del miércoles de ceniza y el segundo en septiembre. El primer vencimiento era variable, ya que dependía de una celebración litúrgica móvil que se celebraba entre febrero y marzo, por lo que el pago debía tener lugar entre julio y agosto, de manera que las dos liquidaciones solían abonarse muy próximas en el tiempo. Puede que esa fuera la causa de la modificación de tales términos, ya que posteriormente la primera tanda fue fijada en Pascua Florida, entre el 22 de marzo y el 25 de abril, y el segundo abono para la feria de septiembre. ${ }^{33}$

31 AMB, Actas del Concejo, 1469-70, f. 33v.

32 AMB, Pergaminos, 8/4.

33 AMB, Actas del Concejo, 1469-70, ff. 5-v. 


\section{El protagonismo del linaje Entenza en el devenir del Barbastro bajomedieval}

El linaje Entenza estuvo enraizado en sus orígenes en la zona de la Ribagorza, tomando su nombre de la torre de Entenza, ${ }^{34}$ situada en el Prepirineo aragonés, y se estructuró en diversas ramas de gran transcendencia. Una de ellas, que mantuvo la posesión de la torre de Entenza, así como otras propiedades en Aragón, se extendió por la zona de Vandellós, Tivisa, Mora de Ebro y Pratdip, al emparentar en el siglo XIII Guillén de Entenza ${ }^{35}$ con la familia Subirats-San Martí, descendiente de los Castellvell. A partir de 1324 esta zona pasó a denominarse baronía de Entenza, tras un pacto establecido en 1313 entre el rey Jaime II y Guillén de Entenza, nieto del citado Guillén de Entenza y Alamanda de Subirats-San Martí y primogénito de Berenguer de Entenza.

Otra rama de la familia Entenza extendió sus dominios por la zona de Alcolea de $\mathrm{Cinca}^{36}$ y estuvo relacionada con la ciudad de Barbastro desde la conquista cristiana. En el siglo XIII hay constancia de que Gombaldo de Entenza, hijo de Bernat Guillén de Entenza, heredó de su padre la baronía de Alcolea, así como diversas propiedades en la ciudad de Barbastro, entre las que se contaba el castillo y la morería, situada en La Fustería. El patrimonio de la familia fue considerablemente ampliado gracias al enlace de Gombaldo con Constanza de Antillón, bisnieta de Ponce I de Urgel y IV de Cabrera, conde de Urgel y vizconde de Áger, nieta de Rodrigo Álvaro de Cabrera-Urgel e hija de Sancho de Antillón, ${ }^{37}$ mayordomo y alférez real, y de Leonor de Cabrera-Urgel, heredera de los condes de Urgel. Dicho enlace supuso la unión de la baronía de Alcolea con la de Antillón, que estaba integrada por Antillón, Ponzano, Lascellas, Abiego, Bespén, El Grado, Artasona, Osso, Pertusa, Puy de Cinca, Sit, Astella, Abizanla, Val Solana, Alhurre, Samitier y Morcat (Ubieto, 1983: 333-334).

Teresa de Entenza, hija legítima de Gombaldo y Constanza, fue nombrada por su padre heredera universal de todos sus bienes en el testamento que otor-

34 En el año 1063 Arnau Mir de Tost y su esposa Arsenda donaron a Miró Gombau un terreno en dicho solar para que construyese allí un castillo (Fité, 1985; Pastor, 2004: 40).

35 Señor de Ráfales y de Entenza, en el reino de Aragón, y de Castellnou y Puig de Santa María, en el reino de Valencia.

36 Incluyendo Alerre, Castelflorite, El Grado, Samitier, Guaso, Morcat, Abizanda, Solana, Graus, Secastilla, Artasona, Clamosa y Puy de Cinca.

37 Se considera a Juan Galíndez de Antillón como el fundador de este importante linaje, el cual fue distinguido por su valor en la conquista de Zaragoza en 1118 al servicio del rey Alfonso I. Posiblemente falleció en la batalla de Fraga de 1134. (Ubieto, 1981: 67). 
gó en septiembre de 1304 en Alcolea de Cinca, al no tener descendientes legítimos varones (Pastor, 2004: 123-142). En dicho documento el otorgante estableció que su hija Teresa recibiese los castillos y villas de Alcolea, Castelflorite y Ráfales (Ubieto, 1983: 329), así como el heredamiento de Barbastro, además de localidades al sur del reino de Aragón, como la villa de Manzanera, y otros enclaves en el reino de Valencia, entre los que se encontraban Chiva y Gestalgar. A pesar de que los dominios de Gombaldo de Entenza fueron muy extensos, tanto en el reino de Aragón como en el de Valencia, Navarra e incluso Castilla, estuvo muy ligado a Alcolea de Cinca. Por ese motivo solicitó en su testamento ser enterrado en la iglesia de San Juan de dicha localidad, concretamente en una capilla en honor de Santa María que él mismo ordenó construir, donde estableció dos capellanías perpetuas. ${ }^{38}$

Tras el fallecimiento de su padre en 1309, Teresa de Entenza recibió las baronías de Antillón y Alcolea (Ubieto, 1983: 332), así como la baronía de Entenza del reino de Aragón y una serie de posesiones al sur de Aragón y Valencia. ${ }^{39}$ Pero además de los bienes paternos, Teresa también heredó por línea materna el condado de Urgel en 1314, al fallecer sin descendencia su tío abuelo Armengol X, conde de Urgel y vizconde de Áger (Madrazo, 1839: 249), el mismo año en el que casó con el infante Alfonso. La renuncia al trono de Jaime, hermano de Alfonso, que decidió tomar los hábitos en 1319, supuso la coronación del infante Alfonso, convirtiéndose en el rey Alfonso IV en 1327. A pesar de ello Teresa de Entenza no llegó a ser reina porque falleció cinco días antes de la subida al trono de su esposo.

Por tanto, durante el primer cuarto del siglo XIV converge en la Corona el patrimonio de dos de las ramas principales de la familia Entenza. Por un lado Teresa de Entenza aportó a su matrimonio con el infante Alfonso las baronías de Alcolea, Antillón y Entenza, todas en el reino de Aragón, en 1314. Mientras que el rey Jaime II recibió poco después, en 1321, la donación de la baronía de Entenza, situada en el principado de Cataluña, por parte de Guillén de Entenza, además del castillo y villa de Entenza, en la Ribagorza. A pesar de esta confluencia, todo este patrimonio no conformó una unidad en ningún momento y fue transmitido por diferentes vías. Los bienes asumidos por Jaime II fueron cedidos en 1324 a su hijo Ramón Berenguer, momento en el que dicho patrimonio situa-

38 Legó 15000 sueldos dineros jaqueses sobre la villa y castillo de Figueruela para sustento de dos clérigos, una manceba y trece pobres de manera perpetua. (Pastor, 2004: 124).

39 Las villas de Ráfales, Castelflorite y Manzanera fueron reservadas para su madre, Constanza de Antillón. 
do en el principado de Cataluña recibió la denominación de baronía de Entenza, título que perduraría hasta el siglo XIX. El infante Ramón Berenguer permutó esta baronía junto con el condado de las montañas de Prades, de nueva creación, con su hermano Pere, a cambio del condado de Ampúrias (Romero y Palet, 2014). En cambio el patrimonio aportado por Teresa de Entenza fue transmitido a su hijo Jaime junto con el condado de Urgel, de manera que se convirtió en Jaime I de Urgel, vizconde de Áger y barón de Entenza, Antillón y Alcolea.

Las heredades que la familia Entenza poseía en Barbastro fueron donadas en 1324 por los infantes Alfonso y Teresa, en calidad de condes de Urgel, a Guillén de Entenza, hermano de la citada Teresa, como compensación por sus servicios a la Corona y en agradecimiento a su fidelidad. ${ }^{40}$ Los titulares de estos bienes gozaban de jurisdicción alta y baja, civil y criminal, mero y mixto imperio. Además tenían derecho sobre las aguas, molinos y caza, así como sobre el paso del bestiar, ${ }^{41} \mathrm{y}$ disfrutaban de la potestad de recaudar numerosos tributos y exacciones, algunos de ellos de jurisdicción real, lo que conformaba una serie de concesiones difícilmente conjugables con los emergentes derechos de la sociedad urbana.

Tras el fallecimiento de Guillén de Entenza, los bienes recayeron en Jaime, hijo de Teresa de Entenza y del rey Alfonso IV, junto con el vizcondado de Ager y las baronías de Antillón y Alcolea, a causa de la defunción de su hermano Sancho, heredero universal de Teresa de Entenza. En su testamento, otorgado en Zaragoza el 23 de octubre de $1327,{ }^{42}$ Teresa ya estipuló que si fallecía su hijo Sancho, pasaría a ser Jaime su heredero universal, el cual ejerció de conde de Urgel entre 1336 y 1347. Tras su fallecimiento todo su legado fue cedido a su hijo Pedro, posteriormente Pedro II de Urgel, pero durante la minoría de edad de éste fue su madre, Cecilia I de Cominges-Turenne, quien ejerció de condesa de Urgel y señora de las propiedades barbastrenses.

A pesar de existir una clara línea hereditaria entre los descendientes directos de Teresa de Entenza, debe remarcarse que hubo una disociación entre el dominio directo de los bienes barbastrenses de la familia, en manos de los

40 AMB, Legajos, D1-3.

41 Derecho a cobrar una tasa por el paso de ganado por sus heredades.

42 Elige su sepultura en el monasterio de San Francisco de Lérida. Instituye capellanías perpetuas en la iglesia de San Juan de Alcolea de Cinca, en la capilla donde descansaba Gombaldo de Entenza, por el alma de su padre; en la iglesia del monasterio de Cabas, por el alma de su madre Constanza; y en la iglesia de Bellpuig por su antepasado Armengol, conde de Urgel. También instituye capellanías por su alma y la de todos sus parientes en Santa María de Salas, en Santa María del Pilar y en Santa María de Montserrat. (Pastor, 2004: 150-162). 
condes de Urgel, y el dominio útil de los mismos, ejercido durante la segunda mitad del siglo XIv por el caballero Manuel de Entenza, consejero del rey, hermanastro de Teresa de Entenza e hijo natural de Gombaldo de Entenza, y por sus descendientes. Estas propiedades fueron incorporadas al patrimonio real en $1417^{43}$ como represalia por el alzamiento en armas de Jaime II de Urgel contra Fernando I, considerado crimen de lesa majestad (De la Torre, 2013).

El año 1453 supuso un punto de inflexión en Barbastro, ya que en ese año el rey Alfonso V restituyó a María Jiménez de Entenza el dominio directo sobre los bienes que tradicionalmente habían pertenecido a su familia. En realidad este hecho podría parecer de relativa importancia para el municipio, ya que los Entenza habían mantenido el disfrute de su patrimonio durante toda la primera mitad del siglo XV, pero tal reintegración de las propiedades supuso la acentuación del poder señorial de la familia en la ciudad, hecho potenciado todavía más con el enlace de María Jiménez de Entenza con Rodrigo de Rebolledo, hombre de confianza del rey Juan de Navarra, gobernador general del reino y posteriormente rey de Aragón, con el que tuvo una excelente relación de fidelidad. Este noble, natural de Castrojériz, en el reino de Castilla, formó parte desde su niñez de la casa real de Navarra, donde fue camarero mayor y gran privado del rey (Castán, 2006: 405). Junto con María Jiménez de Entenza, su segunda esposa, tuvo un hijo legítimo, llamado Lope de Rebolledo y Entenza, el cual llevó a término diversos pleitos con la familia materna por el señorío de Entenza y con la familia paterna para obtener el mayorazgo de Monclús, Salas Altas y Salas Bajas. ${ }^{44}$

La familia Entenza, reforzada por la recuperación a mediados del siglo XV de los derechos sobre las propiedades alienadas, optó por imponer premisas feudales en una ciudad en evolución y crecimiento, en parte por la asunción de una reestructuración social derivada de la fractura creada en 1414 con la con-

43 AMB, Pergaminos, 5/10.

44 Rodrigo de Rebolledo había estado casado en primeras nupcias con María de Palafox, enlace que supuso la unión de las familias Palafox y Rebolledo. María heredó el señorío de Ariza de su madre Constanza, que a su vez lo había obtenido de su hermano Antón de Palafox tras fallecer sin descendencia. En el caso del mayorazgo y sucesión de la casa de Ariza se utilizó el apellido Palafox de Rebolledo y en el del mayorazgo de Monclús, Salas Altas y Salas Bajas, el apellido Rebolledo de Palafox. Rodrigo de Rebolledo tuvo dos hijos varones con María de Palafox, Juan de Rebolledo y Palafox y Guillén de Palafox y Rebolledo. El primogénito, Juan, fue abad de los monasterios de Montearagón y de San Victorián, así como señor de la baronia de Monclús y de Salas Altas y Bajas. Guillén heredó la casa Palafox, razón del cambio de orden de sus apellidos, y tras el fallecimiento de su hermano Juan, también recibió los señoríos de Monclús, Salas Altas y Salas Bajas. El último descendiente de Rodrigo de Rebolledo y de su tercera esposa, Violante de Torrellas, fue Martín de Rebolledo y Torrellas, el cual se retiró a Montearagón y no tuvo sucesión. 
versión forzosa de gran parte de la aljama judía barbastrense. A ello se sumaron las reformas de los órganos del gobierno municipal, a causa de imposiciones externas y necesidades internas, ya que la ciudad debía asumir en sus estructuras de poder el nuevo orden social citado, además de dar respuesta a las crecientes necesidades de la población. La insaculación fue el sistema utilizado para aunar las fuerzas emergentes de la ciudad con los anhelos feudales nobiliarios y la pretensión de control por parte del monarca, impuesto en 1454, un año después de que la familia Entenza recuperase los derechos sobre su patrimonio barbastrense.

Rodrigo de Rebolledo y María Jiménez de Entenza utilizaron sus redes familiares y de solidaridad para expandir su poder, ejerciendo diferentes medidas de coacción para imponerse al orden establecido. Los partidarios de Rebolledo entraban armados en la ciudad con total libertad, a pesar de las recurrentes advertencias del concejo al respecto de portar armas en la urbe y de los estatutos existentes. Durante la segunda mitad del xv el concejo estuvo especialmente preocupado por la seguridad ciudadana a causa de los numerosos conflictos externos que afectaban al municipio y por el desarrollo de bandos internos que desestabilizaron la armonía urbana.

La documentación referente a la familia Entenza, concretamente a la rama ligada a la baronía de Alcolea de Cinca, permite constatar el deseo de perduración del linaje que queda patente tanto en las transmisiones de bienes como en las capitulaciones matrimoniales y en los testamentos. En ellos se observa una necesidad de preservar el linaje a lo largo del tiempo y de salvaguardar la unidad de la casa Entenza frente a nuevas parentelas y bienes patrimoniales que podían hacer diluir su esencia primigenia, como así aconteció al albor de la Edad Moderna, todo un ejemplo de reproducción de patrones pertenecientes a una cultura del linaje (Fentress y Wickham, 2003).

El nombre de la familia, claro indicador de sus orígenes, y las armas del linaje conformaban un capital simbólico que debía ser legado, protegido y enaltecido. La plasmación heráldica de las armas de la familia suponía la representación gráfica del linaje, símbolo de su estatus y también marca de propiedad, ya que denotaba de manera pública la pertenencia a la familia tanto de bienes inmuebles como de lugares especialmente significativos, como capillas y lugares de enterramiento, lo que a su vez servía para engrandecer todavía más su fama y subrayar su posición social. Por tanto, se trata de una creación expresa de la memoria de la familia dirigida a fomentar, expandir y hacer perdurar las claves del linaje a través de los tiempos (Atienza, 1997: 41-59). 
La significación del nombre y las armas era tal, que si los descendientes no asumían estas señas de identidad del linaje podían perder todos los derechos hereditarios que tuvieran sobre los bienes de la familia. Así lo hace constar Gombaldo de Entenza en su testamento, en el que especifica que «si el dito heredero mio non prenda el sobrenompne e las armas d'Entiença, segunt dito yes, que pierda todo el dreyto que yo le lexo e que se sigua la ordinacion, por mi aqui feta, de los ditos bienes» (Pastor, 2004). En este documento también queda patente la preocupación del pater familias por preservar el patrimonio familiar tras haber emparentado con la realeza, en un intento de evitar que tales bienes fuesen asimilados por la Corona. Por esta razón Gombaldo de Entenza estipuló que su heredera universal, su hija Teresa de Entenza, transmitiese el patrimonio de su linaje a su segundo hijo varón, siempre que no fuese religioso, ya que el primogénito debía heredar los bienes de su padre, es decir, del rey Alfonso IV. También especificó que en el caso de que el primer hijo varón quisiese heredar el patrimonio materno, los bienes paternos serían cedidos al segundogénito, con el fin de «que los ditos casales no vingan a un heredero, e que cada uno d'ellos ditos casales haya su heredero con el sobrenompne e con las armas de cada uno» (Pastor, 2004). De igual manera su hija Teresa de Entenza también instituyó como heredero de su linaje a su segundo descendiente varón, Sancho, aunque a causa de su temprana muerte fue su hijo Jaime quien heredó los bienes de este linaje y su primogénito, futuro Pedro IV, recibió el patrimonio de su padre, el rey Alfonso IV.

Además del apellido y la heráldica, es necesario destacar la relevancia de las mandas pías dentro del imaginario cultural de las elites, ya que se trataba de otra manera de remarcar su prestigio y hacerlo perdurar a lo largo del tiempo (Solórzano, 2002: 437). En el caso de los miembros de la familia Entenza que residieron en la ciudad de Barbastro, queda constancia de la fundación por su parte de dos capillas en Santa María la Mayor. En el siglo XIII, Bernardo Guillén de Entenza ordenó construir una capilla bajo la advocación del Corpus Christi y, a principios del xv, Teresa de Entenza estipuló en su último testamento la realización de una capilla en el altar de San Pedro de la citada iglesia, bajo la advocación de Santa María y San Pedro, con el fin de que reposasen allí tanto sus restos como los de su familia. Isabel de Entenza, hija de la citada Teresa, también expresó en sus últimas voluntades su deseo de que fuera construida una capilla en Santa María, en donde estaba enterrada su familia, encargo que recayó en Juan Jiménez Cerdán, su esposo y ejecutor testamentario, pero parece que no llegó a cumplirse esta última voluntad (Lozano, 2008). 


\section{La irrupción del contingente converso como nuevo elemento de poder en el entramado urbano barbastrense}

Un elevado porcentaje de los ciudadanos que formaban parte del gobierno municipal barbastrense en el siglo Xv eran conversos, procedentes de las familias judías de la ciudad que optaron por aceptar la fe cristiana en torno a 1414 y permanecer en el municipio en lugar de emigrar a otras localidades manteniendo su religión. La integración de este colectivo en el concejo fue bastante ágil y en pocos años controlaron los resortes del poder municipal, apoyados en su potencial económico, el cual a menudo servía para sufragar las mermadas rentas de la ciudad. Este proceso se llevó a cabo de manera bastante fluida gracias a que no se impuso en ningún momento la limpieza de sangre como condición para acceder el gobierno urbano, requisito indispensable en otras ciudades, como en el caso de Zaragoza. En cambio en Barbastro únicamente se tuvo en cuenta que los oficiales poseyeran armas y caballo para ser considerados hábiles para ejercer un cargo municipal, lo que se trataba de un claro mecanismo de selección dentro de la población urbana (Hinojosa, 1988: 45; Lafuente, 2014: 37-43).

Las trayectorias trazadas por las familias conversas de Barbastro durante el siglo Xv tuvieron una evolución diversa, primordialmente en función del patrimonio que dichos núcleos familiares atesoraron durante su etapa como judíos, ya que este nivel de riqueza fue la clave para su entronque en el seno de la sociedad cristiana barbastrense. A fines del siglo XIV y primeros años del XV las familias judías con mayor relevancia tanto en el ámbito comercial como en el fiduciario fueron los Conparat, Avincacez y Sanoga, pero a través de la documentación no se ha podido hallar el paralelismo de estas familias con los apellidos adoptados tras el bautismo. Además debe tenerse en cuenta que tras la conversión de la aljama barbastrense, parte de estos judíos emigraron y, a su vez, conversos de otros territorios se trasladaron a la ciudad. Únicamente ha quedado constancia de que Pablo de Santángel, barbero, habitante en Barbastro, se llamaba Salamón Conparat antes de su conversión y que procedía de Monzón (Sesma, 1991: 122).

Dos de las familias conversas más destacadas de la urbe fueron los Lunel y los Santángel. A través del análisis del comportamiento de sus miembros se ha podido confirmar su integración temprana en el organigrama concejil, pocos años después de su conversión, y su relevante participación en las actividades comerciales y financieras de la ciudad. La expansión de los censales como 
medio para hacer frente a los continuos y cada vez más elevados gastos del concejo fue la clave de la estrecha vinculación entre el capital converso y las estructuras de poder de la ciudad. Su considerable patrimonio fue la llave de acceso al gobierno urbano y, una vez en el poder, esos mismos grupos familiares se consolidaron como la fuente económica de los préstamos del municipio, dando lugar a una retroalimentación entre las necesidades económicas del concejo y el incremento de fortuna y poder de las citadas familias conversas. Pero esta fructífera relación fue trastocada en gran medida en el último cuarto del siglo Xv a causa de la implantación del tribunal inquisitorial.

Durante los dos últimos decenios del siglo xv el devenir de las familias conversas presentadas con anterioridad cambió de rumbo de manera radical a causa de las actuaciones llevadas a cabo por los tribunales inquisitoriales, de manera que gran parte de las fortunas por ellos atesoradas pasaron a engrosar el patrimonio real. La lucrativa convivencia mantenida durante gran parte del Cuatrocientos entre los neófitos barbastrenses y los cristianos viejos de la ciudad se vio truncada a partir de la irrupción del Santo Oficio, concretamente desde la instauración del tribunal inquisitorial en la zona de Barbastro y Monzón en julio de 1486 (Pallarés, 1996: 37). La mayoría de los miembros de las citadas familias conversas fueron investigados y gran parte de ellos finalmente condenados, incluso aquellas personas que habían fallecido mucho tiempo atrás, como aconteció en el caso de los hijos de Pedro de Santángel.

\section{Consideraciones finales}

Barbastro fue una de las grandes ciudades medievales de Aragón durante la Edad Media, con una significativa capacidad productiva y una relevante competencia organizativa de un amplio espacio del reino. Gracias a su destacada ubicación, en los siglos bajomedievales se produjo una evolución de ciudad eminentemente agrícola a enclave esencial de intercambios comerciales entre ámbitos económicos complementarios. Este desarrollo se produjo fundamentalmente en el xv, ya que durante los siglos precedentes el carácter rural de la ciudad tuvo un protagonismo casi absoluto. En el siglo XIV las actividades tradicionales estaban ligadas a la tierra, así como el endeudamiento que formaba parte de la vida cotidiana. En la mayoría de los casos se trataba de transacciones pagadas a plazos o bien pequeños créditos, siempre devueltos en breves espacios de tiempo, que servían tanto para la subsistencia de la familia como para la realización de pequeñas inversiones en otras actividades, fundamentalmente agrícolas, según las 
posibilidades de cada individuo. Pero a finales del Trescientos se observa una evolución de los pequeños créditos particulares, controlados en su gran mayoría por los judíos, y de los treudos, monopolizados por la Orden del Hospital de San Juan de Barbastro, hacia el uso de una nueva tipología, basada en la devolución de capital a largo plazo e intereses menores mediante censales, primero enfitéuticos y posteriormente totalmente desligados de la propiedad de la tierra.

Este último tipo de fórmula crediticia, de gran difusión durante el xv, tuvo un protagonismo destacado en la reestructuración del gobierno urbano que tuvo lugar durante el Cuatrocientos. La necesidad ingente de efectivo por parte del concejo fue cubierta mediante la emisión de censales que, a partir del segundo decenio del siglo xv, fueron comprados por aquellos conversos que decidieron permanecer en la ciudad tras la expulsión de los judíos en torno a 1414. Los relevantes patrimonios de las familias judías de finales del siglo XIV favorecieron una posición clave para que esta minoría fuera escalando y afianzándose en la estructura de poder de la ciudad, inicialmente en el ámbito económico y, posteriormente, también en el político. Su potencial financiero, junto con la aceptación de la doctrina cristiana, fueron los dos factores que permitieron la integración de la minoría judía dentro del entramado social preestablecido, aprovechando también un momento de cambio y de reestructuración de la organización municipal, coyuntura crucial que supieron aprovechar para convertirse en pieza primordial del mismo. Por ese motivo la expansión de los censales como medio para hacer frente a los continuos y cada vez más elevados gastos del concejo fue el origen de la estrecha vinculación entre el capital converso y las estructuras de poder de la ciudad. Este nuevo contingente pudo integrarse con cierta rapidez en el organigrama concejil debido a que su riqueza se convirtió en una de las vías principales de sustento de las mermadas finanzas municipales. El patrimonio de los conversos fue la llave de acceso al gobierno urbano y, una vez en el poder, esas mismas familias se consolidaron como la fuente económica de los préstamos del municipio, generando una retroalimentación entre las necesidades económicas del concejo y el incremento de fortuna y poder de las nuevas familias conversas.

Rey y nobleza son los dos factores que complementan el panorama expuesto hasta el momento. Barbastro era una ciudad de realengo y, como tal, dependía de forma directa del rey y su administración recaía en funcionarios reales. Por tanto la evolución y progresiva complejidad de la estructuración del poder urbano debía ser conjugado con los intereses del monarca, centrado en defender las regalías de la Corona y en mantener en pacifico estado la ciudad, ya 
que una fructífera autogestión de la urbe suponía beneficios para la Corona. Por último, debe tenerse en cuenta que desde los orígenes de Barbastro como ciudad cristiana, nobles de relativa importancia intentaron obtener réditos de la explotación de la urbe, pero al tratarse de territorio de realengo, tales pretensiones solían ser frenadas en cierta medida desde la Corona, aunque la estrecha vinculación con la familia Entenza desdibujó en más de un momento las diferencias entre realengo y señorío.

Por todo ello la ciudad de Barbastro en la Edad Media se convierte en el escenario ideal para analizar el nacimiento y evolución de las estructuras concejiles, así como la pugna de fuerzas entre ciudadanos e infanzones por conseguir el poder municipal y la inserción del contingente converso en la organización urbana. La conversión de los judíos barbastrenses a principios del siglo xv y la integración de las familias más pudientes en el organigrama municipal y en las finanzas del concejo constituyeron un nuevo factor de renovación del equilibrio de poder. La implantación de la insaculación en la ciudad en el año 1454 supuso la legitimación del reparto de poder entre las fuerzas en conflicto, pero este sutil equilibrio se vio de nuevo trastocado durante el último cuarto del siglo XV a causa de la implantación del tribunal del Santo Oficio en la zona de Barbastro-Monzón. La persecución y condena de gran parte de la elite conversa, totalmente integrada en la sociedad barbastrense, dio lugar de nuevo a un desequilibrio de poder en el concejo que tuvo que ser solventado desde la Corona mediante numerosas injerencias en el devenir político de la urbe. El paso al siglo Xvi estuvo marcado por la desmembración de gran parte de las familias conversas más significativas, así como de su patrimonio, y por la disolución del linaje Entenza en la ciudad de Barbastro.

\section{Referencias bibliográficas}

ANGOY, J. L. (1984), «Colección diplomática del concejo de Barbastro. Cartas reales y privilegios», Annales, Acuerdo de esponsales entre Petronila de Aragón y Ramón Berenguer IV de Barcelona, número monográfico, 133-135.

ANGOY, J. L. (1988), «Guía metodológica para el estudio de la insaculación de cargos concejiles a través de los libros de actas», Metodología de la investigación científica sobre fuentes aragonesas, 3, 323-334.

ARANDA, F. J.; SANZ, P. (2003), «Burgués o ciudadano en la España moderna: una conceptualización historiográfica» en F. J. Aranda (coord.), Burgueses o ciudadanos en la España Moderna, Cuenca, Ediciones de la Universidad de Castilla La Mancha, 21-68. 
ARCO, R. (1946), «De la Edad Media en el Alto Aragón», Estudios de Edad Media de la Corona de Aragón, II, 433-468.

ATIENZA, I. (1997), «La construcción de lo real. Genealogía, casa, linaje y ciudad: una determinada relación de parentesco» en J. Casey y J. Hernández (dir.), Familia, parentesco y linaje. Congreso Internacional Historia de la Familia. Nuevas perspectivas sobre la sociedad europea, Murcia, Universidad de Murcia, 41-59.

BALAGUER, F. (1950), «La ciudad de Barbastro y las negociaciones diplomáticas de Ramiro II», Argensola. Revista del Instituto de Estudios Oscenses, 2, 133-158.

BATLLE, C. (1988), «Esquema de l'evolució del municipi medieval a Catalunya», Estudis baleàrics, any $\mathrm{V}, \mathrm{n} .^{\circ}$ 31, 61-72.

BIELSA, M. ${ }^{a}$ A. (1961), «Notas sobre la repoblación de Barbastro en el siglo XII», Argensola. Revista del Instituto de Estudios Oscenses, 47-48, 187-222.

BLASCO DE LANUZA, V. (1619), Historias eclesiásticas y seculares de Aragón, Zaragoza, J. de Lanaja y Quartanet.

CABEZUDO, J. (1963), «Los conversos de Barbastro y el apellido Santángel», Sefarad. Revista del Instituto Arias Montano de Estudios Hebraicos y Oriente Próximo, XXIII, 265-284.

CASTÁN, M. A. (2006), «Historia nobiliaria de la villa de Ariza. La casa de los Palafox. Estudio Genealógico-Nobiliario», Hidalguía, 316-317, 399-440.

CATEURA, P. (2006), Els impostos indirectes en el regne de Mallorca: Les imposicions sobre l'alimentació (segle XIV), Palma de Mallorca, El Tall Editorial.

DE LA TORRE, S. (2016), «Grandes negocios urbanos de finales del siglo XIV: el arrendamiento de ingresos fiscales de Zaragoza», en C. Laliena y M. Lafuente (coords.), Consumo, comercio y transformaciones culturales en la Baja Edad Media: Aragón, siglos XIV-XV, Zaragoza, Grupo de investigación CEMA, Universidad de Zaragoza, 185-210.

DE LA TORRE, S. (2013), «Por hacer paz y justicia: la traición como arma política durante el Interregno en el reino de Aragón (1410-1412)», e-Spania [online], URL: http://e-spania.revues.org/22001; DOI: 10.4000/e-spania.22001.

FALCÓN, M. ${ }^{a}$ I. (1978), Organización municipal de Zaragoza en el siglo XV, Zaragoza, Universidad de Zaragoza.

FALCÓN, M. a I. (1997), «Finanzas y fiscalidad de ciudades, villas y comunidades de aldeas aragonesas», Finanzas y fiscalidad municipal, V Congreso de Estudios Medievales, Ávila, Fundación Sánchez Albornoz, 239-274.

FALCÓN, M. a I. (1999), «El sistema fiscal de los municipios aragoneses», Corona, municipis i fiscalitat a la Baixa Edat Mitjana, Lleida, Institut d'Estudis Ilerdencs, 191-218.

FENTRESS, J.; WICKHAM, C. (2003), Memoria social, Madrid, Cátedra.

GARCÍA, J. V. (1993), Los sistemas alimentarios en la Valencia bajomedieval, Valencia, Diputación de Valencia. 
GIMÉNEZ, A. (1944), La Edad Media en la Corona de Aragón, Barcelona, Labor. GUINOT, E.; MIRA, A. J. (2008), «Fiscalidad urbana y distribución y consumo de la producción agrícola en Valencia (siglos XIV-XV)», en R. Vallejo (ed.), Los tributos de la tierra. Fiscalidad y agricultura en España (siglos XII-XX), Valencia, Publicaciones de la Universidad de Valencia, 137-161.

HINOJOSA, J. (1988), «El municipio valenciano en la Edad Media: características y evolución», Estudis baleàrics, any V, n. ${ }^{\circ}$ 31, 39-59.

HUESCA, R. de (1807), Teatro histórico de las Iglesias del Reyno de Aragon, IX, Zaragoza, Oficina de Miedes.

IRANZO, M. ${ }^{\mathrm{a}}$ T. (2005), Elites políticas y gobierno urbano en Huesca en la Edad Media, Huesca, Ayuntamiento de Huesca.

LACARRA, J. M. a (1982), Documentos para el estudio de la reconquista y repoblación del Valle del Ebro, Zaragoza, Anubar.

LADERO, M. A. (1994), «El ejercicio de poder real en la Corona de Aragón: instituciones e instrumentos de gobierno (siglos XIV y Xv)», En la España Medieval, 7, 31-93.

LAFUENTE, M. (2014), Un reino en armas: la guerra de los Dos Pedros en Aragón (1356-1366), Zaragoza, Institución Fernando el Católico.

LAFUENTE, M. (2016), «Afinidad y violencia. La organización militar de la nobleza aragonesa en los siglos XIII y XIV», Discurso, memoria y representación. La nobleza peninsular en la Baja Edad Media, XLII Semana de Estudios Medievales de Estella, Pamplona, Gobierno de Navarra, 180-187.

LALIENA, C. (1996), La formación del Estado feudal. Aragón y Navarra en la época de Pedro I, Huesca, Instituto de Estudios Altoaragoneses.

LALIENA, C. (2000), Pedro I de Aragón y de Navarra (1094-1104), Burgos, La Olmeda.

LALIENA, C.; IRANZO, M. ${ }^{\text {a }}$ T. (1998), «Poder, honor y linaje en las estrategias de la nobleza urbana aragonesa (siglos XIV-Xv)», Revista d'Història Medieval, 9, 41-79.

LEDESMA, M. a L. (1990), Cartas de población, fueros y ordinaciones municipales de Aragón. Tercera Muestra de Documentación Histórica Aragonesa, Zaragoza, Centro de Documentación Bibliográfica Aragonesa, Diputación General de Aragón.

LÓPEZ, S. (1981), Historia de la muy noble y muy leal ciudad de Barbastro, Zaragoza, Heraldo de Aragón. [1 ${ }^{\mathrm{a}}$ ed. 1861, Barcelona, Pablo Riera].

LÓPEZ, J. I. (2008-2009), «Un amanamiento á o estudio de o lesico churidico aragonés como lenguache teunico», Luenga \& fablas, 12-13, 75-105.

LOZANO, S. (2008), Las elites en la ciudad de Zaragoza a mediados del siglo XV: La aplicación del método prosopográfico en el estudio de la sociedad [tesis inédita].

MADRAMANY, M. (1788), Tratado de la nobleza de la corona de Aragon, especialmente del reyno de Valencia, comparada con la de Castilla, Valencia, José y Tomás de Orga. 
MADRAZO, P. de. (1839), Recuerdos y bellezas de España: Cataluña, Barcelona, Imprenta de Joaquín Verdaguer.

MATEOS, J. A. (2003), «Propios, arbitrios y comunales: la hacienda municipal en el reino de Aragón durante los siglos XVI Y XVII», Revista de Historia Económica, XXI, 51-77.

MATEOS, J. A. (2005-2006), «Municipio y mercado en el Aragón moderno: el abasto de carne en Albarracín durante la segunda mitad del Seiscientos», Espacio, Tiempo y Forma, Serie IV, Historia Moderna, 18-19, 105-132.

MUÑOZ, T. (1847), Colección de fueros municipales y cartas pueblas de los reinos de Castilla, León, Corona de Aragón y Navarra, Madrid, Imprenta de José María Alonso.

NARBONA, R. (2007), «Algunas reflexiones sobre la participación vecinal en el gobierno de las ciudades de la Corona de Aragón (ss. XII-XV)», Res publica: revista de filosofía política, 17, 113-150.

NARBONA, R.; CRUSELLES, J. M. ${ }^{\text {a }}$ (1995), «El sistema de abastecimiento frumentario de la ciudad de Valencia en el siglo Xv: entre la subvención pública y el negocio privado», XIV Jornades d'Estudis Històrics Locals, 305-332.

NAVARRO, G. (2006), «Conquista cristiana y feudalismo: las tierras del Somontano en la Edad Media» en M. N. Juste (coord.), Comarca del Somontano de Barbastro, Zaragoza, Gobierno de Aragón, 87-100.

Ordinaciones reales de la ciudad de Barbastro (1657), Zaragoza, Herederos de Pedro Verges.

ORTI, P. (1999), «Les imposicions municipales catalanes au XIV siècle», en D. Menjot y M. Sánchez (coord.), La fiscalité des villes au Moyen Âge (Occident méditerranéen). 2. Les systemes fiscaux, Toulouse, 423-445.

PALLARÉS, M. A. (1996), Ápocas de la receptoría de la Inquisición en la zona nororiental de Aragón (1487-1492), Huesca, Centro de Estudios de Monzón y Cinca Medio.

PASTOR, M. (2004), El cartulari de Xestalgar: memòria escrita d'un senyoriu valencià, Barcelona, Fundació Noguera.

QUADRADO, J M.. (1844), Recuerdos y bellezas de España: Aragon, Madrid, Jose Repullés.

RAMOS, J. M. (1981), Los fueros de Sobrarbe, Zaragoza, Institución Fernando el Católico.

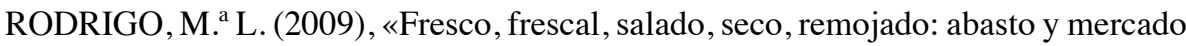
de pescado en Aragón (siglos XII-XV)», en B. Arízaga y J. A. Solórzano (coord.), Alimentar la ciudad en la Edad Media. Encuentros Internacionales del Medievo, Nájera, Instituto de Estudios Riojanos, 547-577.

ROGEL, C. (dir.) (2005), Derecho nobiliario, Madrid, ed. Reus.

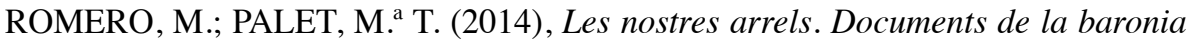
d'Entença: Vandellòs, Coll de Balaguer i l'Hospitalet de l'Infant, Tarragona, Ajuntament de Vadellòs i l'Hospitalet de l'Infant i Arola Editors. 
RUBIO, A. (2012), «Después de Caspe. El urgelismo y las oligarquías», en J. Á. Sesma (coord.), La Corona de Aragón en el centro de su Historia, 1208-1458. El Interregno y el Compromiso de Caspe (1410-1412), Zaragoza, Grupo de Investigación CEMA, 265-292.

SÁINZ DE LA MAZA, R. (1998), El monasterio de Sijena. Catálogo de documentos del Archivo de la Corona de Aragón, vol. II, Barcelona, CSIC. Institución Milá y Fontanals.

SÁIZ, J. (2004), Guerra y nobleza en la Corona de Aragón. La caballería en los ejércitos del Rey (Siglos XIV-XV), Valencia, Universidad de Valencia [tesis inédita].

SÁNCHEZ, M. (2010), «La monarquía y las ciudades desde el observatorio de la fiscalidad», en J. Á. Sesma (coord.), La Corona de Aragón en el centro de su Historia, 1208-1458. La Monarquía aragonesa y los reinos de la Corona, Zaragoza, Grupo de Investigación CEMA, 45-66.

SANTAMARÍA, A. (1988), «El municipio en el reino de Mallorca», Estudis baleàrics, any $\mathrm{V}, \mathrm{n} .^{\circ}$ 31, 5-36.

SESMA, J. Á. (1987), El establecimiento de la Inquisición en Aragón (1484-1486). Documentos para su estudio, Zaragoza, Institución Fernando el Católico.

SESMA, J. Á. (1991), «Los Santángel de Barbastro: estructura económica y familiar». Aragón en la Edad Media, IX, Zaragoza, Universidad de Zaragoza, 121-136.

SESMA, J. Á. (2011), El Interregno (1410-1412). Concordia y compromiso político en la Corona de Aragón, Zaragoza, Institución Fernando el Católico.

SESMA, J. Á. (coord.) (2012), La Corona de Aragón en el centro de su Historia, 1208-1458. El Interregno y el Compromiso de Caspe (1410-1412), Zaragoza, Grupo de Investigación CEMA.

SESMA, J. Á.; LALIENA, C. (2000), «La población de Barbastro y sus estrategias políticas y económicas a mediados del siglo XV», Revista d'Història Medieval, 10, 123-160.

SOLÓRZANO, J. A. (2002), Santander en la Edad Media: patrimonio, parentesco y poder, Santander, Universidad de Cantabria.

TORRAS, J. M. ${ }^{a}$ (1986), «El procedimiento insaculatorio en los municipios de los reinos de la Corona de Aragón, entre la renovación institucional y el sometimiento a la monarquía (1427-1714)», Jerónimo Zurita, su época y su escuela, Zaragoza, Institución Fernando el Católico, 341-352.

UBIETO, A. (1951), Colección Diplomática de Pedro I de Aragón y de Navarra, Zaragoza, Escuela de Estudios Medievales, CSIC.

UBIETO, A. (1981), Historia de Aragón. La formación territorial, Zaragoza, Anubar.

UBIETO, M. ${ }^{a}$ I. (1983), Pedro Garcés de Cariñena. Nobiliario de Aragón, Zaragoza, Anubar.

VÁZQUEZ, J. (2011), Ordinaciones y paramientos de la ciudad de Barbastro publicados por D. Mariano de Pano, Barbastro, Ayuntamiento de Barbastro. 
VV.AA. (2013), El compromiso de Caspe (1412), cambio dinásticos y constitucionalismo en la Corona de Aragón, XIX Congreso de Historia de la Corona de Aragón, Zaragoza, Gobierno de Aragón, Cortes de Aragón e Ibercaja.

ZURITA, J. (2003), Anales de Aragón. Canellas, A. (ed.), Iso, J. J.; Yagüe, M. ${ }^{\text {I.; }}$ Rivero, P. (ed. electrónica), Zaragoza, Institución Fernando el Católico. 